\title{
THE EFFECTIVENESS OF TEACHING READING BY USING JUMBLED PICS STORIES
}

\author{
${ }^{1}$ Lenny Eka Saputri \& ${ }^{\mathbf{1}}$ Muhamad Sofian Hadi \\ ${ }^{1}$ Faculty of Education, University of Muhammadiyah Jakarta, Indonesia \\ Corresponding Author Email: lennyekas7@gmail.com
}

\begin{tabular}{|c|c|}
\hline Article Info & Abstract \\
\hline $\begin{array}{l}\text { Article History } \\
\text { Received: February } 2021 \\
\text { Revised: March } 2021 \\
\text { Published: April } 2021\end{array}$ & \multirow{2}{*}{$\begin{array}{l}\text { The research aimed to find out the effectiveness of jumbled pics stories in the } \\
\text { teaching of reading skills for the } 9^{\text {th- }} \text { grade students at SMP Al-Fitroh Tangerang. } \\
\text { The method used in this research was the quantitative method which is a pre- } \\
\text { experimental design by implementing pre-test and post-test design. In this study, } \\
\text { the researcher used } 15 \text { students as a sample. The data were corrected by pre-test } \\
\text { and post-test as instruments. The result of the study was calculated using a t-test. } \\
\text { The findings showed that students' post-test mean scores were } 64.33 \text {. It was } \\
\text { higher than the pre-test mean-scores (71.86). Meanwhile, the score of the t-test } \\
\text { (7.92) was higher than the t-table. The finding indicated that Jumbled Pics } \\
\text { Stories is an effective medium to improve student's reading. The jumbled pics } \\
\text { stories guide students to connect what they have already understood with texts } \\
\text { being read. Therefore, Jumbled pics stories can be applied to other language } \\
\text { skills to improve vocabulary and reading comprehension. }\end{array}$} \\
\hline $\begin{array}{l}\text { Keywords } \\
\text { Jumbled Pics Stories; } \\
\text { Teaching Reading; }\end{array}$ & \\
\hline
\end{tabular}

How to cite: Saputri, L.E., \& Hadi, M.S. (2021). The effectiveness of teaching reading by using jumbled pics stories, JOLLT Journal of Languages and Language Teaching, 9(2), 179-187, DOI: https://doi.org/10.33394/jollt.v\%vi\%i.3531

\section{INTRODUCTION}

Language allows people to communicate with great precision. Language plays an important role in communication, especially in international information exchange. It plays a major role in the communication that many people are interested in. With language, people can give information about the world, diplomacy, commerce, and trade and share ideas through language, both written and oral. According to Grabe and Stoller, as cited in Ahmadi (2018), language has become one of the main essential points influencing foreign exchange practices. Students use various aspects of their language ability, such as listening, speaking, reading, and writing, regarding their communication skills.

English is the most popular foreign language. It means that people from various countries choose English as a universal way of communicating with others. As cited in Kardemir and Gorgoz (2019), Kruzel states learning in different languages requires the preparation of four basic skills and the practice of students who are using those skills. Among the four skills, reading is indeed one of the skills that students must understand because it's an important element to make a good activity in communication (Wahid \& Todore, 2021; Hanan et al., 2020). By reading, students can get new vocabularies, get further information, and get the opportunities to create and share the information by writing. Chaudhry and Al-Adwani (2019) state reading is a process, a way of thought, and an activity that requires multiple essential features.

Reading is a skill that should be taught from the early stages. As cited in Daskalovska (2018), Palmer states reading is a large amount of text "quickly and carelessly" and relies on meaning rather than grammar. Therefore, Caretti et al. (2019) state reading needs the processing abilities required to identify letters, sequences of letters, and words correctly and fluently. However, processing textual information requires both fluent and correct reading and 
interpretation of its content (Bruen, 2019; Rohmah, 2018). Reading is expected to be able to improve students' critical thinking skills (Haerazi \& Irawan, 2020) and help students have the insight to write (Cooney et al. 2018). Also, through reading, students get knowledge related to national and international issues in various fields that link language skills and content (Mutiarani and Rahman, 2019).

In the teaching process, teachers should know how to make teaching and learning more attractive. As cited in Ismail et al. (2017), Richard and Schmidt make sure that performance and morale are the principles and ideas that teachers get about appropriate approaches to teaching and learning and that act as the foundation for some of their choice. In teaching language, the teacher cannot do teaching and learning activities without any guidance. The guidelines for this phase are the curriculum, the syllabus, and the lesson schedule. Moreover, the teacher also should know how the learning process will be carried out. Teachers can use an effective approach, interactive method, and innovative ways to make a successful learning process.

According to Cetinkaya et al. (2019), interactive reading activities require better language exposure, encourage the development of performance and spelling, improve vocabulary competence, and develop important fundamental literacy skills. In addition, immersive book reading experiences stimulate brain sections linked to story understanding and conceptual imagination. However, Kussumaningtyas (2016: 2) mentions however most teachers use school textbooks and other printed content to teach their students. They select school textbooks as the primary source of learning and receive secondary language from other sites, such as the internet, journals, magazines, etc. Teaching reading can be successful if it is facilitated by attractive classroom learning. Dedi Junaedi as librarian Expert of the National Library, in 2019, Indonesian reading interest is currently ranked 16th out of 30 countries in the world. It is because of technological progress and awareness of the people in Indonesia of the importance of reading. However, In learning reading, it should be possible to understand the content of the text and the context and purpose of the text, and, of course, the author's goal. If students' reading skill is low, it will make difficulties in learning another skill.

In this case, the teacher has the responsibility to guide students besides also giving students support and motivation so that they can improve their English skills. There are many teaching methods to help teachers more easily convey material, for example, by using media or games to solve the problem. Thomas, as cited in Morshidi et al. (2019) mentions attractive reading approach by using learning media can be a solution to face a problem, especially in learning reading. It can make students easier to understand the material and concepts taught. The use of media allows students to understand teaching material better. Using media also makes students see themselves in the teaching and learning process. Some of the kinds of media that might help them to deliver the materials are song, picture, rhyme, models, puppets, etc. (Yolanda \& Hadi, 2019)

As a teacher, it is critical to determine new teaching forms of media to solve the difficulties and encourage students. Teachers used toys, images, songs, physical objects, cartoons, or movies as media learning. By using media in the learning experience will enhance the student's curiosity in the classroom activities. However, the use of media in the learning process should be suitable. Anderson, as cited in R. Nasution (2019) classify media into ten types such as Audio, Print, Audio Print, Proyeksi Visual Silent, Audio Visual Projection Silent, Visual Motion, Audio Visual Motion, Physical Object, Human and Environment and the last one is Computer. One of the learning media that will increase student's interest in reading is using pictures. A picture is still one of the media that teachers can use in teaching reading. It makes students interest in the learning process. Jazuli et al. (2019) state that using pictures allows students to distinguish between their previous knowledge and foreign vocabulary that they seek to understand. 
Using pictures can be used as an alternative way in the language learning process. As Wright (2019), as cited in Fadillia, states, the picture helps students retell their interactions or comprehend something to portray the location, the object, the people, etc. The picture consists of descriptions and meanings that are to be portrayed. It depends on the student's own creativity or perception to generate words connected to the picture. Sinclair (2017), as cited in Lavalle and Briesmaster, also states that a Picture is classified as a clear description or image that is formed, drawn or captured, and made on a flat surface. The main aspect of an image is its clear visibility to readers. However, the teacher should take care when reading while using the picture as a medium. The picture should be relevant to the subject. Teachers have to deliberately select the right pictures to suit the topic of the lesson. Pictures should be marvelous and interesting ones. Seeing is a sense that students are used to understanding. Students want to see a beautiful object, and the picture will last in their minds for a period of time, or even permanently (Panigrahi, 2009).

Jumbled pics stories are one of the solutions to increase student's reading ability. Jumbled pics stories are puzzle pictures which display randomly. Astuti (2019) also mention that a Jumbled picture is a collection of unintentionally mixed pictures that contain storyline events that readers need to arrange in an orderly sequence. Students must be interested in the pictures and feel challenged because the text will be randomly used. Students also feel free to explore and free to be creative. Jumbled Pics Stories were used to encourage students' involvement in the teaching process. This present study was expected to explore the significant effect after using jumbled pics stories in teaching reading based on the description above. Precisely for grade $9^{\text {th }}$ students at SMP Al-Fitroh Tangerang in the academic year 2020/2021.

\section{RESEARCH METHOD Research Design}

A quantitative approach has been used in this research. The researcher wants to know the use of Jumbled Pics Stories improve students reading skills. Quantitative is one the method that researchers determine what to study, ask precise questions, gather quantifiable data from the participants, analyze specific numbers using statistics, and perform the survey in an impartial, quantitative way (Cohen et al., 2018). The data of this study comprise numbers, which are students' reading achievement after treatment.

In a quantitative study, there are pre-experimental, true-experimental, and quasiexperimental research designs. Meanwhile, the design was used in this study was a preexperimental design, also known as one group pre-test and post-test. Then, the researcher has only compared the result based on the student's pre-test and post-test. The one-group pretestposttest design involves a single group that was pre-test $(\mathrm{O})$, treatment $(\mathrm{X})$, and post-test $(\mathrm{O})$. In this research study, this research population covered all ninth-grade students of SMP AlFitroh Kota Tangerang in the academic year of 2020/2021. In the current study, all population was selected as the research sample because they are less than 100 students. Those consist of 15 students. The ninth-grade students are subjected to Jumbled Pics Stories as the learning strategy to improve and develop students' reading skills.

\section{Instruments}

To gain the data, the researcher used reading tests. The test was provided in pre-test and post-test sessions. The researcher used a test in collecting the data from students which the data being as a sample of the research. The researcher used the pre-test before treatment and used the post-test after treatment. In order to carry out the pre-test and post-test, the students were asked to answer multiple-choice questions personally. Treatment was given to the students after the end of the pre-test, and it was six meetings, including the pre-test and posttest, and the researcher used Jumbled Pics Stories as learning media in teaching reading. The 
post-test was designed to measure the effectiveness of Jumbled Pics Stories in teaching reading.

\section{Data Analysis}

In this study, the students are asked to answer 20 multiple choice questions in the pretest and post-test. The questions are taken from the student's textbook. Based on the score, researchers classify some criteria, which are excellent, good, enough, poor, and very poorthe data obtained from the score of both pre-test and post-test. The researcher was analyzed the result of the test statistically and presented it in the form of means and standard deviation. The researcher analyzed the result quantitatively using IBM SPSS 22 to determine the effectiveness of using jumbled pics stories in teaching reading.

\section{RESEARCH FINDINGS AND DISCUSSION Research Findings}

This study aims to investigate the effectiveness of jumbled pics stories in the teaching of reading skills for the $9^{\text {th- }}$ grade students at SMP Al-Fitroh Tangerang. The use of jumbled pics stories helps students read various texts in the form of picture stories as much as possible. This article explores the research finding and discussions that answering the questions of the research. The research question is what the Jumbled Pics Stories affect student's reading. The description of the reading comprehension requirement criteria and pre-test and post-test reading comprehension could be classified into the following data.

Table 1

\begin{tabular}{ccccccc}
\multicolumn{2}{c}{$\begin{array}{c}\text { Table 1 } \\
\text { Criteria of Student's Pre-test and Post-test Reading Comprehension }\end{array}$} \\
No & Classification & Category & \multicolumn{2}{c}{ Frequency } & \multicolumn{2}{c}{ Percentage (\%) } \\
\hline & & & Pre-test & Post-test & Pre-test & Post-test \\
\hline 1. & $90-100$ & Excellent & 0 & 0 & $0 \%$ & $0 \%$ \\
\hline 2. & $76-89$ & Good & 0 & 5 & $0 \%$ & $33.33 \%$ \\
\hline 3. & $66-76$ & Enough & 4 & 7 & $26.67 \%$ & $46.67 \%$ \\
\hline 4. & $40-65$ & Poor & 11 & 3 & $73.33 \%$ & $20 \%$ \\
\hline 5 & $00-39$ & Very Poor & 0 & 0 & $0 \%$ & $0 \%$ \\
\hline & Total & & 15 & 15 & $100 \%$ & $100 \%$
\end{tabular}

After categorization of student's reading criteria, it is shown in the table above, the pre-test result of the students can be described. In the reading class, students have equal reading comprehension. It was proven by the reading test in Table 1 . It showed that none of the students were very poor $(0 \%)$, but 11 students were poor $(73.33 \%)$, four students were enough (26.67\%), 0 students were good $(0 \%)$, and there were no students who got excellent $(0 \%)$. Based on the table above, the post-test result of the students can be described. None of the students were very poor $(0 \%)$, three students were poor $(20 \%)$, seven students were enough $(46.67 \%)$, five students were good $(33.33 \%)$, and there were no students who got excellent $(0 \%)$. Based on the students' pre-test and post-test outcomes above, the diagram and statistical result score of pre-test and post-test have shown in Diagram 1. 


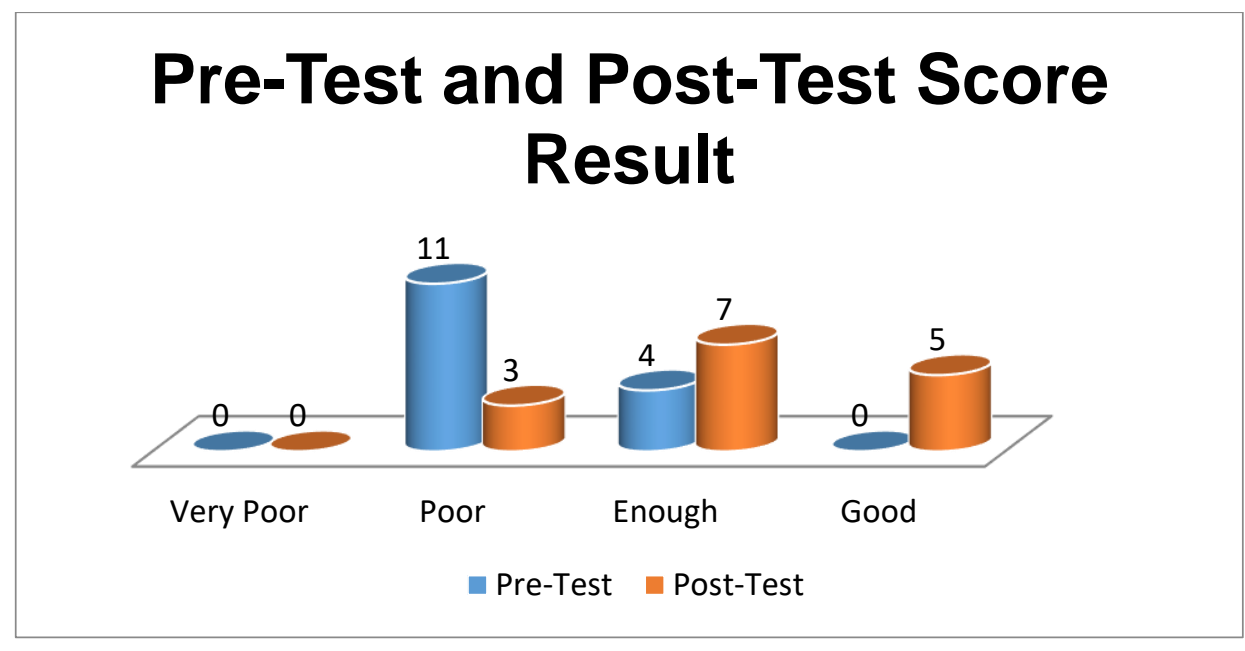

Diagram 1

Pre-test and Post-test Score Result

Table 2

The Result of Pre-test and Post-test

\begin{tabular}{cccc}
\hline Group Test & N & Mean & Standard Deviation \\
\hline Pre-test & 15 & 64.33 & 5.93 \\
\hline Post-test & 15 & 71.87 & 5.81 \\
\hline
\end{tabular}

Based on the table above, from the first output, paired samples statistics table showed pre-test mean's score was 64.33 while post-test mean's score was $71.86, \mathrm{~N}$ referred to total amount of the sample i.e. 15. Standard deviation showed the heterogeneous that occurred in the data before and after teaching reading through jumbled pics stories were 5.936 and 5.817. It showed that there was a statistically significant difference within pre-test and post-test results. Therefore, the normality test was conducted in order to know whether the data were normally distributed or not, as this present table below:

Table 3

Test of Normality

\begin{tabular}{cccc}
\hline \multirow{2}{*}{ Group Test } & \multicolumn{3}{c}{ Shapiro-Wilk } \\
\cline { 2 - 4 } & Statistic & df & Sig. \\
\hline Pre-test & .891 & 15 & .070 \\
\hline Post-test & .938 & 15 & .357 \\
\hline
\end{tabular}

Based on the calculation table of normality data in the Shapiro-Wilk test section above, the sig. score for the pre-test is $0.070>\alpha(0.05)$, and the post-test sig. result is $0.357>\alpha$ $(0.05)$. The pre-test and post-test results is better than $\alpha=0.05$, meaning the pre-test and posttest data are standard and the data should be taken forward to the next statistical test.

Table 4

T-test Paired Sample Test

\begin{tabular}{|c|c|c|c|c|c|c|c|c|}
\hline \multicolumn{9}{|c|}{ Paired Differences } \\
\hline & \multirow[t]{2}{*}{ Mean } & \multirow[t]{2}{*}{$\begin{array}{c}\text { Std. } \\
\text { deviation }\end{array}$} & \multirow[t]{2}{*}{$\begin{array}{l}\text { Std. } \\
\text { Error } \\
\text { Mean }\end{array}$} & \multicolumn{2}{|c|}{$\begin{array}{l}\text { 95\% Confidence } \\
\text { Interval of the } \\
\text { Difference }\end{array}$} & \multirow[t]{2}{*}{$\mathrm{t}$} & \multirow[t]{2}{*}{ df } & \multirow[t]{2}{*}{$\begin{array}{l}\text { Sig. (2- } \\
\text { tailed) }\end{array}$} \\
\hline & & & & Lower & Upper & & & \\
\hline Pair 1 pre test - post test & $-7,53333$ & 3.68136 & .95052 & -9.57200 & -5.49467 & -7.925 & 15 & .000 \\
\hline
\end{tabular}


Based on the calculation of the t-test, the data showed significant results in which the result of the mean score was 7.533. the standard deviation was 3.681. the standard error was 0.950, the lower interval was 9.572, and the upper interval was 5.494, the result t-test was 7.925, degree of freedom was 1 , and significance (2-tailed) was $0.00<\alpha(0.05)$. If the significance score is lower than $\alpha=0.05$, it can be concluded that there was a different significant result before and after conducting treatment with Jumbled Pics Stories.

\section{Discussion}

This study aims to investigate the effectiveness of teaching reading by using jumbled pics stories in ninth-grade students. In the junior high school level, teaching reading is accomplished by using a range of reading resources. Therefore, the English teacher should choose the materials that are suitable for the stage of the student. It is in line with In Indonesia, teaching and learning English, specifically in teaching reading, is based on the National Curriculum Standard (SBC). A school-based curriculum is a curriculum designed on the basis of each level of the academic institution. Sadoski (2015), as cited in Aprilia, states The aim of teaching reading is to encourage students or learners to discover knowledge from the word combination in the text and to do so in a consecutive manner at a fair pace without actually expressing what is being read. Teaching reading is controlled by teachers and students and systems or content (Haris et al., 2019; Januarty, 2018).

In this study, the researchers finished researching the effectiveness of teaching reading by using jumbled pics stories. The researcher held this research by teaching at a class of $9^{\text {th- }}$ grade students of. The cumulative number of students who participated in this study was 15 students. This research was done to figure out the significant difference in the student's score before and after using Jumbled Pics Stories in teaching reading. Based on the series of the calculation above the researcher concludes that the data was generally conveyed and homogenous. The result can be seen at the normality test of table normality data in the Shapiro-Wilk test section above, the pre-test sig. score is $0.070>\alpha(0.05)$, and the result of post-test sig. is $0.357>\alpha(0.05)$. The result for both the pre-test and post-test was greater than $\alpha=0.05$, which means the data was normal.

Therefore, pre-test and post-test had a large difference score from the reported result above, and it was proved by having 965 for pre-test and 1078 for post-test. The average pretest score was 64.33 and the average post-test score was 71.86. It means that the pre-and posttest deviations were significant. It can be found that there is a clear gap between the average score from the result of teaching reading with jumbled pics stories and without jumbled pics stories. This can be proven that using picture help students in teaching reading. In line with the result above, by giving the pictures, students can predict and infer from what they hear and read and what they see. Pictures also contribute to making an interesting lesson, improving students' motivation, giving a sense of the language's context, and giving a specific reference point or stimulus (Putri et al., 2019).

The paired samples statistics table above showed that the pre-test means-score was 64.33 while the post-test mean's score was 71.86, $\mathrm{N}$ referred to the total amount of the sample, i.e., 15. Standard deviation showed the heterogeneous that occurred in the data before and after teaching reading through jumbled pics stories were 5.936 and 5.817 and standard error of mean before and after teaching reading through jumbled pics stories were 1.532 and 1.501. In line with paired samples statistics table, paired-samples correlations also showed whether any correlation between the score before and after teaching reading through jumbled pics stories to students. It has been shown that the significance score was $(0.00)<\alpha(0.05)$, and it can be established that there is a significant correlation between teaching reading through jumbled pics stories and without it in the test.

This study result was in line with Astuti (2019) explained that there is a major increase in student reading comprehension skills after teaching Jumbled Pics Stories in second grade 
SMAN 1 Kota Agung. Efficient learning can be accomplished with the use of media in combination with a picture. According to Matulka, as cited in Restanto (2016) a good picture series in a story links the reader to the pictures and generates the implication of the pictures. Story and pictures work together to push the story onward.

On the whole, based on paired sample t-test table, $t$ obtained was 7.92 and $t$ critical at the level of significance $(\mathrm{p})=0.05$ was 2.145 ; meanwhile, if $\mathrm{t}$ obtained $\geq \mathrm{t}$ critical at the level of significance $(p)=0.05$. Then significant (2-tailed) is equal 0.00 with significant level $\alpha=0.05$ (2-tailed). it can be concluded that there was a significant result before and after conducting treatment with Jumbled Pics Stories.

\section{CONCLUSION}

Based on the pre-test and post-test data's complete findings, the significant differences were shown by a total pre-test score of 965 and a total post-test score of 1078. After that, the average pre-test score was 64.33 , and the average post-test score was 71.68. Therefore, it can be concluded that the effectiveness of teaching reading by using jumble pics stories has a significant influence on reading comprehension for students. It has been proven by the $\mathrm{t}$-test result in paired sample test that the value of $t$ obtained was 7.92, and the value of $t$ critical at the level of significance $(\mathrm{p})=0.05$ was 2.145 .

\section{ACKNOWLEDGEMENT}

Researchers would like to express our deep gratitude to all who provided us the possibility to complete this study. Therefore, the researcher wishes to give appreciation and thanks to all colleagues who have support and giving comments in any part of this article. Criticisms or suggestions from the readers very much expected to perfection this article. Furthermore, researchers hope this article can help readers to add scientific specialties.

\section{REFERENCES}

Ahmadi, M.R. 2018. The use of Technology in English Language Learning: A Literature Review. International Journal of Research in English Education. 3(2):116

Aprilia, N. 2015. Improving Reading Comprehension of the Eight Grade Students at SMPN 6 Yogyakarta Through Pose Strategy in the Academic Year of 2014/2015. Thesis of English Education in State University of Yogyakarta

Astuti, D. 2019. Teaching Reading Through Picture Series In Narrative Text at the Second Grade Students of SMAN 1 Kota Agung. Thesis of English Education in University of Lampung

Bruen, J. (2020). Language learning strategies for reading comprehension: assessing the strategy use of young adults at beginners' level taking Chinese, German, Japanese or Spanish as foreign languages at university. Language Learning Journal, 48(2), 170 186. https://doi.org/10.1080/09571736.2017.1370606

Carretti, B., Toffalini, E., Saponaro, C., Viola, F., and Cornoldi, C. 2019. Text Reading Speed in a Language With a Shallow Orthography Benefits Less from Comprehension as Reading Ability Matures. British Journal of Educational Psychological Society. 1

Cetinkaya, F.C., Ates, S., And Yildirim, K. 2019. Effect of Interactive Book Reading Activities on Improvement of Elementary School Students \&rsquo: Reading Skills. International Journal of Progressive Education. 15(3):181

Chaudry, A.S. and Al-Adwani, A. 2019. Reading Practice of EFL Students: A Survey of Kuwaiti College Students. English Language Teaching. 12(5):30 
Cohen, L., Manion, L., \& Morrison, K. (2018). Research Methods in Education (8th Edition). New York: Routledge.

Cooney, A., Darcy, E., \& Casey, D. (2018). Integrating reading and writing: Supporting students' writing from source. Journal of University Teaching and Learning Practice, 15(5).

Daskalovska, N. 2018. Extensive Reading and Vocabulary Acquisition. 28

Fadilia, E.C. 2019. The Use of Picture Series to Improve Student's Speaking Skill in Teaching Recount Text at the First Grade of SMA Kartikatama Metro. Thesis of English Education in University of Lampung.

Haerazi, \& Irawan, L. A. (2020). The effectiveness of ECOLA technique to improve reading comprehension in relation to motivation and self-efficacy. International Journal of Emerging Technologies in Learning, 15(1), 61-76. https://doi.org/10.3991/ijet.v15i01.11495

Hanan, A., Muhlisin, M., \& Suadiyatno, T. (2020). Actuating reading comprehension through genre-based directed reading thinking activities (G-BDRTA) viewed from critical thinking skills. Journal of Languages and Language Teaching, 8(4), 402-411. doi: https://doi.org/10.33394/jollt.v8i4.2778

Harris, K. R., Ray, A., Graham, S., \& Houston, J. (2019). Answering the challenge: SRSD instruction for close reading of text to write to persuade with 4th and 5th Grade students experiencing writing difficulties. Reading and Writing, 32(6), 1459-1482. https://doi.org/10.1007/s11145-018-9910-1

Ismail, H., Syahruza, J.K., and Basuki. 2017. Improving the Student's Reading Skill Through Translation Method. Journal of English Education. 2(2):126

Januarty, R. (2018). Extensive Reading (ER) Practices and the Development of Language Fluency. Lingua Cultura, 12(3), 267. https://doi.org/10.21512/lc.v12i3.4063

Jazuli, A.J.M., Din, F.F.M., and Yunus, M.M. 2019. Using Picture in Vocabulary Teaching for Proficiency Primary pupils via PI-VOC. International Journal of Academic Research in Business and Social Sciences. 9(1):314

Karademir, C.A and Gorgoz. 2019. English Teacher's Problem Encountered in Teaching Four Basic Language Skills. International Education Studies. 12(4):118

Kussumaningtyas, A. 2016. Developing Interactive Multimedia Program for Learning Reading for Tenth Grade Students in SMAN 1 Cangkringan. Thesis of English Education in State University of Yogyakarta

Lavalle, P.L., and Briesmaster, M. 2017. The Study of the Use of Picture Descriptions in Enhancing Communication Skills Among the 8th Grade Students-Learners of English as a Foreign Language. 9(4): 3

Mutiarani, and Rahman, I.A. 2019. Theme Based Instruction Model in Teaching Extensive Reading. English Language in Focus (ELIF). 2(1): 45

Morshidi, A., Embi, M.A., and Hashim, H. 2019. Instagram Application: An Active Tool in Cultivating Reading Behaviour. Journal of Information System and Technology Management. Vol 4(11): 97

Nasution, A.K. 2019. Youtube as Media in English Language Teaching (ELT) Context: Teaching Procedure Text. Journal of Ultimate Research and Trends in Education. 1(1): 29

Panigrahi, S. S. (2009). Teaching of English. New Dehli. A P H Publishing Corporation. 
Putri, F.A., Mustajib, A., Maizarah. 2019. A Study on Student's Ability in Using Picture on Reading Descriptive Text at $10^{\text {th }}$ grade MA Sabilal Muhtadin Tembilahan. J-Shelves of Indragiri. 1(1): 6

Restanto, M. 2016. The Use of Picture Book in Teaching Reading for Junior High School Students. Journal of English and Education. 4(2): 51

Rohmah, H. (2018). The Implementation of Herringbone Technique in Reading Comprehension at Second Semester of Non-English Department. Celt: A Journal of Culture, English Language Teaching \& Literature, 18(1), 59. https://doi.org/10.24167/celt.v18i1.555

Yolanda, D., and Hadi, M. S. 2019. Using Puppet Games in Teaching Speaking for Tenth Graders of Senior High School. English Language in Focus (ELIF). 2(1): 3

Wahid, J., Irawan, I., \& Tidore, S. (2021). The effectiveness of electronic whiteboards on students' reading skills. Journal of Languages and Language Teaching, 9(1), 69-76. doi: https://doi.org/10.33394/jollt.v9i1.2953 